\title{
THE SUPINE INESSIVE CONSTRUCTION IN SALACA LIVONIAN
}

\author{
Miina Norvik, Helle Metslang, and Karl Pajusalu \\ University of Tartu
}

\begin{abstract}
The supine inessive form in Salaca Livonian appears in a copular construction or as a sole predicate, and is usually associated with progressive and futurate readings. The linguistic data analysed in this study consist of example sentences in Salaca Livonian that are provided with Latvian, German, and/or Swedish translations. The data originate from the 19th century when Livonian was still spoken by Livonian-Latvian bilingual speakers in the northern part of Latvia. The present paper aims to study the functions and possible development of the supine inessive construction in detail, including the possibility of contact-induced change. The study takes a functional-typological and usage-based approach. We suggest that the usages of the supine inessive form reveal both language-internal development as well as instances of contact-induced development, more precisely reanalysis of Latvian forms with a similar function and/or form.
\end{abstract}

Keywords: progressivity, future time reference, contact-induced change, finitisation, Salaca Livonian

DOI: https://doi.org/10.12697/jeful.2018.9.2.10

\section{Introduction}

Salaca Livonian is a variety of Livonian that was once spoken on the shores of the Salaca River in the northern part of present-day Latvia. The language faded out of use by the end of the 19th century but not without linguistic traces. The most comprehensive amount of linguistic data on Salaca Livonian was collected in 1846 by Anders J. Sjörgen and published in the Livonian grammar (1861a) and dictionary (1861b) that were both completed by Ferdinand J. Wiedemann. The linguistic data were recently rechecked and glossed by Eberhard Winkler and Karl Pajusalu and published as Salis-Livisch I. J. A. Sjögrens Manuskript (2016) and Salis-Livisch II. Grammatik und Wörterverzeichnis (2018). These sources were also used for the purposes of the present study. 
This paper studies the functions and possible development of the supine $^{1}$ inessive construction in Salaca Livonian. The corresponding construction consists of

i. the copula + main verb in the supine inessive form (here also referred to as the $m(V) s$-form) (1).

(1) Sie om schÿ̈-mi-s. (LivS; p. 193²)

it be.3SG eat-SUP-INE

'It [s/he] is eating'

Er ist am Essen (Ger)

he be.3sg at.DAT eating.DAT

han äter (Swe)

he eat. $3 \mathrm{sg}$

ii. the $m(V) s$-form functioning as the sole predicate, which commonly contains the future copula lìd 'will be' (2).

(2) K’inge juurs löudu-b, sie lij-m-s vigali (LivS; p. 311) who.gen at find-3sg it will_be-sup-INE guilty

'At whose place [this] will be found, that [person] will be guilty'

Bei wem [ich es] finde, der wird at who.DAT I it.ACC find:1SG PRON FUT.AUX.3SG

schuldig sein (Ger)

guilty be.INF

Pee kam to atraddifchu, tas buhs wainigs (Lav) at who.DAT this.ACC find:FUT.1SG PRON be:FUT.3sg guilty.M

As the Salaca Livonian (LivS) examples were provided with Latvian (Lav), German (Ger), and/or Swedish (Swe) translations (see 1 and 2) they were also included for comparative purposes. All the examples are presented as they occurred in the original; they are all glossed, but

1 The term supine is used to refer to the infinitive that contains the $m$-element as opposed to the infinitive containing the $t$-element.

2 The Salaca Livonian examples and their equivalents originate from Winkler and Pajusalu (2016). In the article, they are cited using only the page number. The Salaca Livonian examples as well as their translational equivalents are provided with an abbreviation of the respective language. The page number is not repeated when translational equivalents appear on the same page. 
separate translations into English are provided only if they show considerable differences from the translation of the Salaca Livonian example into English.

Previously, the supine inessive construction has received only little attention; merely its main functions have been listed. For instance, Sjögren and Wiedemann (1861a: 139), described the construction as expressing "states in which one finds oneself" (1), they also mentioned the futurate usages with lìd (2) (see also Winkler and Pajusalu 2018: 141). Winkler $(1994,1999)$ subsumed the corresponding forms under the inessive forms of the verbal noun ending in -mi. Norvik (2012) discussed the $m(V) s$-forms in connection with the expression of future time reference. There is no further research that discusses the Salaca Livonian constructions in greater detail or in a broader perspective. Thus, the present paper aims to fill this gap.

As regards Finnish and Estonian, the usage of the supine inessive constructions has been subject to separate studies (see e.g., Metslang 1993, 1995, 2006, Tommola 2010). The constructions are generally associated with the following readings: the locative-final ${ }^{3}$ (3), the progressive (4), and the imminential reading (5). The locative-final reading, which is typically seen as the original meaning of the construction (Metslang 1993: 472), is represented in example (3). As is shown, it may be used with agentive verbs to provide an answer to an inquiry regarding an individual's location. Cross-linguistic findings also show that progressives often go back to locative sources; the development into progressives is typically described as the erosion of the locative meanings (e.g., Bybee et al. 1994: 129, 133, 136). The progressive meaning thus requires an action to go on at reference time; see ex. (4). With respect to progressive marking, Estonian and Finnish are usually listed under those European languages that mark the progressive only optionally, and the simple present or past tense may be used instead (see Thieroff 2000: 294). The supine inessive construction is also used to express an imminential meaning. Namely, when used with achievement and accomplishment verbs, the situation is usually represented as about to take place; see ex. (5).

3 In the studies of the Finnic supine inessive constructions one may encounter the term absentive. Bertinetto et al. (2000: 518) explain it as follows: "a given agent is remote from the deictic centre, performing a certain action". Here, however, the locative-final reading is preferred, as the usages do not tend to reveal any clear connection with the deictic centre. 
(3) Kus Juku on? - Juku on suusata-ma-s (Est; EKS 2017: 120) where Juku be.3sg Juku be.3sg ski-SUP-INE

'Where is Juku?' - 'Juku is [away] skiing'

(4) Meie võistleja on praegu jooks-ma-s we.GEN competitor be.3SG now run-SUP-INE vägaheas tempos (Est; Metslang 1995: 179) very good:INE tempo:INE

'Our competitor is running at a very good tempo now'

(5) Külalise-d on lahku-ma-s (Est; EKS 2017: 120) guest-PL be.3sg leave-SUP-INE

'The guests are about to leave'

The objectives of the present paper are (i) to show the functions of the supine inessive construction occurring as the predicate in Salaca Livonian, (ii) to discuss the possible path of development of this construction, and (iii) to analyse similarities and differences between Salaca Livonian and its contact languages and language varieties (mainly German and Latvian).

The linguistic data originate from the book compiled by Winkler and Pajusalu (2016). All the occurrences of the supine inessive construction that could be found in this source were included in the data set. The study takes a functional-typological and usage-based approach. The analysis is qualitative as the linguistic data on Salaca Livonian are limited and there are instances which could be analysed in multiple ways.

The paper proceeds as follows: section 2 contains an overview of the data, section 3 introduces the results concerning the functions of the supine inessive construction, section 4 includes the discussion and conclusions.

\section{Data}

The Salaca Livonian data, which were collected from Salis-Livisch I. J. A. Sjögrens Manuskript (Winkler and Pajusalu 2016), contained in total 26 examples of supine inessive constructions. Most of these also had translations into Latvian, German, and/or Swedish, which 
we included for comparative purposes. As is shown, Salaca Livonian examples are partly translations of Latvian examples, which Sjögren collected from the Latvian grammar book Lettische Sprachlehre by Heinrich Hesselberg (1841); these examples were also presented with the corresponding Latvian equivalent in the manuscript. In addition, the manuscript contains examples, which do not have any Latvian equivalent; we propose, these were probably originally constructed by Sjögren and then translated into Latvian by a translator; the corresponding examples do not tend to contain the Latvian equivalent, but rather have a Swedish and/or German equivalent. Among the examples of the latter type, it appears there are more cases where the Swedish, German, and Salaca Livonian translation show more discrepancies. (See more in Winkler and Pajusalu 2016: 9-34.) This information is taken into account when analysing the data.

Among these examples, there were 9 instances of $-m(V) s$ appearing as a simple predicate, 7 examples of compound forms containing the present copula (1) or the future copula, and 10 examples of the supine inessive form containing the future copula (2). (See Table 1.) Table 1 is based on 24 examples (out of 26) as there were also 2 instances of converbs (e.g., ex. 7), which will be briefly discussed in section 3.5.

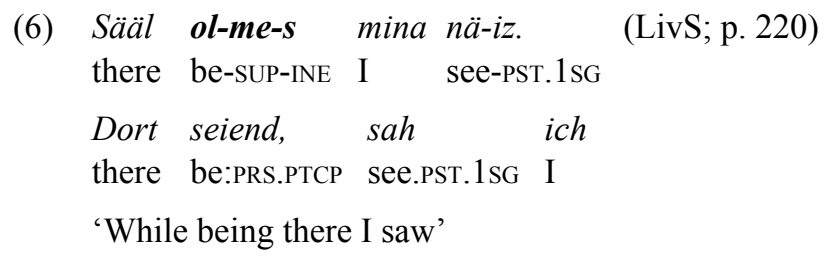

As Table 1 illustrates, the supine inessive form had three variants in the data set: - $m s$ (14 examples), -mes (5 examples), -mis (5 examples). Most of the examples that occurred were instances of $3 \mathrm{Sg}$; there were no instances of $2 \mathrm{Pl}$-forms. The forms with $a b$ in Table 1 are instances of negation ( 8 instances in total).

In some cases it turned out to be important to collect additional data from Salaca Livonian (e.g., it seemed necessary to also discuss the functions of the future copula $l i d$ not used in the supine inessive form); some comparative data from the other variety of Livonian - Courland Livonian - was included as well. The translations into Latvian, German, and Swedish were considered in all cases when outlining the usages of the construction. As the majority of Salaca Livonian sentences did not contain any context (neither did the Latvian equivalents, which served 


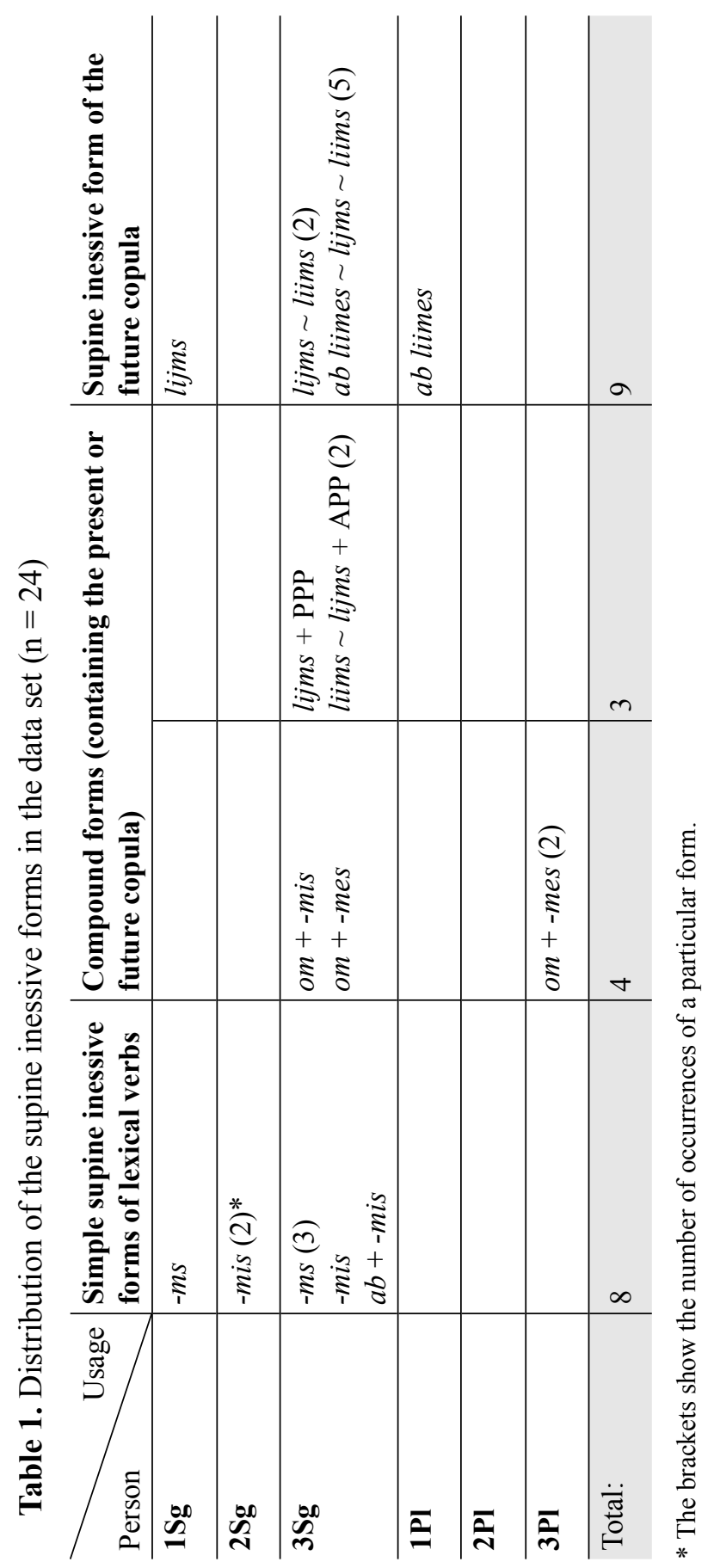


as the basis for the Salaca Livonian translations), on some occasions several interpretations turned out to be possible. As a result of the scarcity of the linguistic material, the method of collecting the data as well as its presentation, multiple interpretations were regarded as inevitable.

As Salaca Livonian examples are translations from Latvian into Salaca Livonian and the speakers back then were bilinguals in Livonian and Latvian, we paid separate attention to analysing the Latvian equivalents in order to detect possible cases of Latvian influence. There were three Latvian forms that particularly interested us:

1. - ams - the present passive participle, which is used to express possibility, e.g., dzerams 'drinkable', zimmējams 'drawable', but which also conveys necessity (7).

(7) Kas tev tur darāms? (Lav; LVG: 578)

what you.DAT there do.PrPp

'What do you need to do there?'

2. -dams - the present active participle, which is used as a converb (8), but which can also convey an ongoing action (9).

(8) Skriedams Hermanis redzēja zirgus. (Lav; LL) run.PrAP Herman see.PST.3SG horse.PL.ACC

'(While) running Herman saw horses'.

(9) Kur iedams? (Lav; Endzelīns 1971: 251) where go.PrAP

'Where (are you) going?'

3. $-\boldsymbol{s}$ - the 3rd person future tense marker, e.g., skries 'will run', dejos 'will dance'.

The examples given above were included due to their similarities in form and/or function: they end in - $m s$ (or only $-s$ ) and can function as sole predicates expressing futurate or modal meanings or an ongoing activity. 


\section{Results: Functions and development}

Table 2 gives an overview of the main results of the analysis, which will be presented in sections 3.1 to 3.5. Whereas Table 1 contained examples presented according to their form, Table 2 also takes into account their functions. The frequency of occurrences in the data set is indicated by the number in parentheses.

Table 2. Functions of the supine inessive constructions in Salaca Livonian.

\begin{tabular}{|c|c|c|}
\hline Function & Form & Examples \\
\hline $\begin{array}{r}\text { Focalised } \\
\text { progressive (3) }\end{array}$ & $\begin{array}{l}\text { Present copula }+\mathrm{SUP}_{\text {Ine }} \\
\mathrm{SUP}_{\text {Ine }}\end{array}$ & $\begin{array}{l}\text { om schyö-mis, om tappli-mes } \\
\text { tul-ms }\end{array}$ \\
\hline $\begin{array}{r}\text { Change-of-state: } \\
\text { Imminential (1) } \\
\text { Gradual } \\
\text { change (2) }\end{array}$ & $\begin{array}{l}\text { Present copula }+\mathrm{SUP}_{\text {Ine }} \\
\mathrm{SUP}_{\text {Ine }}\end{array}$ & $\begin{array}{l}\text { om tul-mes } \\
\text { tul-ms (2) }\end{array}$ \\
\hline $\begin{array}{r}\text { Futurate and/ } \\
\text { or modal (6) }\end{array}$ & $\mathrm{SUP}_{\text {Ine }}$ & $\begin{array}{l}\text { (ab) tul-mis, löydu-mis, } \\
\ddot{a b t u-m i s, ~ a ̈ b ~ t i e d u-m i s, ~ t u l-m s, ~} \\
\text { näe-ms }\end{array}$ \\
\hline $\begin{array}{r}\text { Stative } \\
\text { (durative) }(12)\end{array}$ & $\begin{array}{l}\text { SUP }_{\text {Ine }} \\
\text { Future copula as the } \\
\text { main predicate: } \\
\text { Future copula as the } \\
\text { auxiliary: }\end{array}$ & $\begin{array}{l}\text { (ab) lii-ms } \sim \text { lij-ms (7), } \\
\text { ab lii-mes }(2) \\
l i i-\boldsymbol{m s} \sim l i j-\boldsymbol{m s}(3)+\mathrm{PTCP}\end{array}$ \\
\hline $\begin{array}{l}\text { Converb (outside } \\
\text { the predicate) (2) }\end{array}$ & SUP $_{\text {Ine }}$ & ol-mes, ol-ms \\
\hline
\end{tabular}

\subsection{Focalised progressive}

The focalised progressive can be described as follows: it views the event "as ongoing at a single point in time, but it does not exhaustively localize the event" (Bertinetto et al. 2000: 527). As Table 2 suggests, there were 3 examples that we analysed as instances of the focalised progressive: the main verb of the construction expressed an activity, enabling one to regard the event as ongoing; see (10) and (11). 
(10) Sääll om kana-d liitu-me-s. (LivS; p. 195)

there be.3sG hen-PL peck-SUP-INE

Dort sind die Hühner beim Füttern (Ger)

there are ART hen.PL by.DAT pecking.DAT

'Hens are pecking there'

(11) Sie om schÿ̈-mi-s. (LivS; p. 193)

it be.3SG eat-SUP-INE
Er ist am Essen (Ger)

he be.3sG at.DAT eating.DAT

han äter (Swe)

he eat.3sG

' $\mathrm{S} / \mathrm{he}$ is eating'

Although, in principle, a local-final meaning could also be possible (see also section 1), the translations presented for Salaca Livonian example (11), at least, do not seem to suggest such an option. Namely, German $a m+$ Infinitive + sein (sometimes simply referred to as the am-Progressive) can be primarily associated with a progressive reading (e.g., Anthonissen et al. 2016). The Swedish translation han äter is an instance of a simple present tense, which is also used to convey ongoing activities (Holmes and Hinchliffe 2013). As regards example (10), the beim-construction in the German equivalent may either point to a locative or progressive reading (see Ebert 2000: 630), the Salaca Livonian example (10), however, likely suggests a progressive reading. Additional support comes from Estonian, where such existential clauses with a rhematic subject are shown to play an important role in the grammaticalisation process of the progressive. Namely, their main function is to indicate the presence of the subject at the point of reference; the supine form of the verb primarily conveys existence, and thus, the lexical content of the verb does not tend to be central (cf. Metslang 1995: 175). Still, as the locative reading of the supine form may also be backgrounded, such instances may well be regarded as transitional.

To compare, in the other Livonian variety - Courland Livonian - one does not find clear instances of the focalised progressive, though there are examples of a locative-final reading. For instance, examples (12) and (13) express, first and foremost, being somewhere with a purpose of doing something rather than being in the midst of an activity. It is possible that word order plays a role. For example, in the case of Finnish, 
a progressive reading is associated primarily with instances where the copula and the supine inessive form are not separated (see 14a), whereas the non-progressive reading is preferred for instances where the object comes in between (see 14b). (Berinetto et al. 2000: 525). The Courland Livonian examples go in line with the non-progressive example (14b).



$$
\begin{aligned}
& \text { I be.PST.1sG child.PL.INS potato.PL.PRT pick-SUP-INE } \\
& \text { 'I was off/away picking potatoes with the kids.' }
\end{aligned}
$$

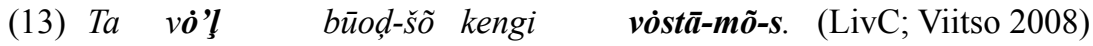
$\mathrm{s} /$ he be.PST.1sG shop-INE shoe.PL.PRT buy-SUP.INE

'S/he was off/away buying shoes in the shop.'
(14) a. Minä ole-n myy-mä-ssä lippu-ja. (Fin) I be-1SG sell-sUP-INE tickets-PL.PRT 'I am selling tickets'
b. Minä ole-n lippu-ja myy-mä-ssä. (Fin) I be-1sg tickets-PL.PRT sell-SUP-INE 'I am off selling tickets'

Although the scarcity of Salaca Livonian data does not allow us to draw any definite conclusions, the German and Swedish equivalents as well as the analogy with the development of the Estonian progressive construction suggest that a progressive reading could be conveyed using the supine inessive construction in Salaca Livonian.

\subsection{Change-of-state: imminential or gradual change}

The data set contained 3 examples of the verb tulla 'come' used in the change-of-state construction to convey imminence (1 example) or gradual change ( 2 examples). As a change-of-state verb, tulla seems to be more commonly used in Salaca Livonian than the cognate verb tūlda 'to come' in Courland Livonian (see more in Norvik 2012, 2014). Although 3 examples in a small data set might not be enough, the large data set of Courland Livonian containing only around 3 examples could suggest that tulla used to be more characteristic of Salaca Livonian. 
Example (15) can be associated with an imminential reading. Such a reading is said to be common with achievement and accomplishment verbs, including with change-of-state predicates (Tommola 2010: 657, EKS 2017: 123). The usage of Salaca Livonian tulla 'to come' in (15) can be compared to that of Estonian saada 'to get; become' in example (16). In these examples, the situation is presented as being in the preparatory phase, i.e., about to take place (e.g., still being 14 years old but soon turning 15). Such a reading of Salaca Livonian example (15) does not seem to be conveyed in the German and Latvian equivalents; these only state the fact of turning fifteen at a future reference point (i.e., during the holidays). Still, judging on the basis of close cognate languages, such as Estonian, there is reason to argue that the Salaca Livonian example expresses imminence.

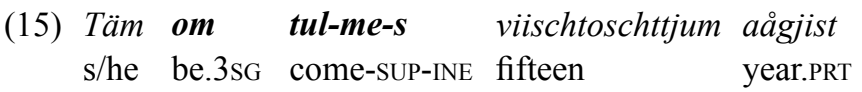

pyä-d päel. (LivS; p. 259)

holiday-PL.GEN on

'S/he is turning fifteen during holidays'

Er wird fünfzehn Jahre zum Fest (Ger)

he FUT.AUX.3sg fifteen year:PL to.DAT holiday

'He will be 15 by the holidays'

winfch nahks peezpadfmit gaddus us

he come.Fut.3sg fifteen year:PL.ACC on

fwehtkeem (Lav)

holidays:PL.DAT

(16) Minu isa-poolne vanaema on saa-ma-s

I.GEN fater-side grandmother be.3sG get-SUP-INE

84 aastase-ks. (Est; etTenTen)

84 year_old-TRA

'My grandmother from father's side is soon turning 84.'

As example (17) reveals, the change-of-state predicate may take a complement in the comparative form (kavalim 'wiser'), and thus view becoming wiser as a gradual process. Again, such a usage is attested in Estonian (e.g., Metslang 2006); see example (18). The difference is 
that whereas examples (15) and (16) express transition between discrete states (being 14 or 15 years old; 83 or 84 years old), examples (17) and (18) convey the sense of continuously becoming increasingly wise/ independent.

$\begin{array}{llllll}\text { Ku } & \text { tul-m-s } & \text { kaval-im, } & \text { sis } & \text { ana-b } & \text { tä- } d-l \\ \text { when } & \text { come-SUP-INE } & \text { wise-COMP } & \text { then } & \text { give-3sG } & \text { you-PL-ADE/ALL }\end{array}$

opatumis-t. (Sal p. 259)

teaching-PRT

Wenn [er] klüger wird, dann gibt [man ihn]

when he wise-сомP become.3sG then give.3sG one he.ACC

euch zum Lehren (Ger)

you.PL.ACC to.DAT teaching

kad nahks gudraks, tad jums dohfchu

when come:FUT.3SG wise-COMP then you.PL.DAT give.FUT.1SG

mahziht] (Lav)

teaching

'When [s/he] will become wiser then I will teach you [him/her?]'

(18) [ Ühesõnaga, valmistu selleks , ] [ et su laps hakkab “ oma isa otsima “ ...

[ kui ta juba iseseisva-ma-ks saa-ma-s

when $\mathrm{s} /$ he already independent-COMP-TRA get-SUP-INE

on. (Est; etTenTen)

be. $3 \mathrm{sg}$

'In a nutshell, be prepared for this that your child will start looking for his/her father ... when s/he is getting more independent.'

In contrast, unlike in example (15), there is no copula in example (17). We propose that instances such as (17) are actually cases of reanalysis of the Salaca Livonian $-s$ of the supine inessive form: relying on the Latvian future marker $-s$, the inessive $-s$ is reanalysed as the future marker, cf. Livonian tul-m-s (come-SUP-INE) and Latvian nahk-s (comeFUT.3sG) (see more in section 3.3). In instances such as (15), which also contain a copula, direct Latvian influence is less likely. 


\subsection{Futurate and/or modal usages}

Whereas examples (15) and (17) express a connection between present and future, examples (19) to (21) can be associated mainly with future time reference. On the one hand, the future interpretation comes from the context (see the use of temporal adverbials, the information given in subordinate clauses); on the other hand, it is possible that the choice of the form also plays a role. For instance, all six examples that occurred in the data set were used without copulas. Again, the finitisation of the supine form could point to adherence to the Latvian model (see discussion in 3.2).

(19) Täm ab tul-mi-s, täma jo om $\mathrm{s} /$ he NEG.3sG come-SUP-INE s/he already be.3sG

kuol-en. (LivS; p. 377)

dead-APP

Er wird nicht kommen, er ist schon

he FUT.AUX.3SG NEG come.INF he be.3sg already

gestorben (Ger)

dead-APP

winfch nenahks, jo winfch jau

he NEG:come:FUT.3SG because he already.3sG

mirris (Lav)

dead.APP.M

' $\mathrm{S} /$ he is not coming, $\mathrm{s} /$ he has passed away already'

(20) Sie päwa pärast $y l$ aådjist löydu-mi-s

it day.GEN after over year.PRT find-SUP-INE

und karn. (LivS; p. 368)

neu.GEN farmstead.GEN

Nach diesem Tag in einem Jahr findest [du]

after this.DAT day in one:DAT year find:2sG you

einen neuen Bauernhof (Ger)

one:ACC new:ACC farmstead

no fchihs deenas pehz gaddu atraddifi jaunas

of this.GEN day.GEN after year.ACC find.FUT.2SG new.PL.ACC

mahjas (Lav)

house.PL.ACC

'On this day after a year you are finding/should find a new farmstead' 
(21)

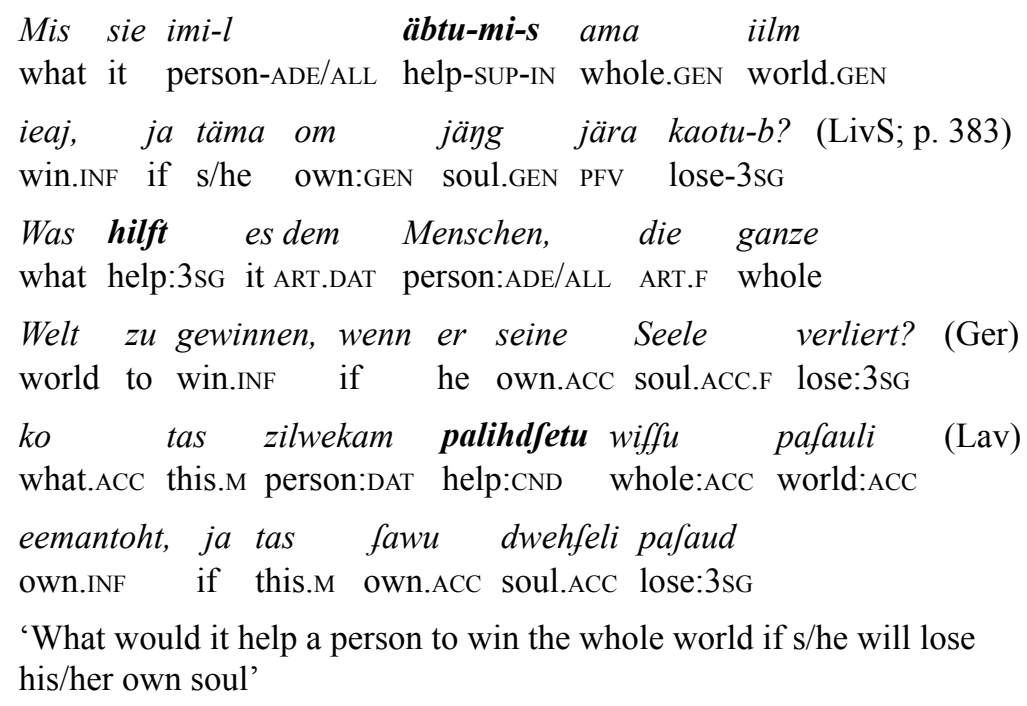

The Salaca Livonian forms dicussed here differ from other examples in the data set as they make use of the mis -form (5 out of 6 instances; see also Table 2). Moreover, there seems to be some modal meaning involved, although it is slightly difficult to determine whether this is due to the use of the mis -form or the status of the future more generally. Namely, we can seldom be entirely confident in future situations; modally, a futurate situation is almost always different from the present and past (Dahl 1985: 103). To compare the translational equivalents, the Latvian equivalent (21), for instance, contains the form palihdfetu 'would help' and can thus be associated with a modal meaning. Although the German translation in (21) contains hilft 'helps', the translation was hülfe 'what would help' was also presented in the original source. Likewise, in addition to findest 'find' in (20), the version sollst $d u$ finden 'should you find' was given as well. The Latvian equivalent in (20), which contains the future tense marker, did not have any parallel version. Example (19) does not explicitly convey a modal meaning either. The fact that someone will not come is presented as a fact, which is supported by the subordinate clause. The German equivalent makes use of the werden + infinitive (also called the Futur I; see e.g., DudenGrammatik 2009), the Latvian equivalent contains the future form with $-s$. Thus, both futurate as modal meanings could be associated with examples (19) to (21).

The data set also contained one instance of the supine inessive form, in which the futurate and participant-external non-deontic modal mean- 
ings seemed to intersect; see (22). Namely, in the Latvian as well as the Salaca Livonian examples, $-s$ could point to the future (as explained in section 3.3, the inessive $-s$ could be reanalysed based on the example of the Latvian future marker and näems could thus have a future meaning). However, there is also an example of the Latvian present passive participle form redsams translated as näemes (Winkler and Pajusalu 2018: 79), which points to a possible modal reading as well, as Latvian -ams can be associated with the expression of possibility (cf. section 2)

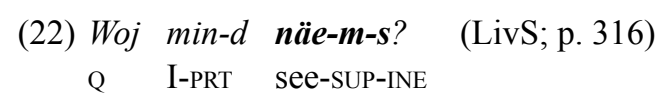

'Will you see me? / Will I be seen?'

\subsection{Future and modal usages with $\operatorname{liim}(e) s \sim \operatorname{lijms}$}

The data set contained 13 instances of $\lim (e) s \sim$ lijms used (i) as the only predicate (10 out of 13); see e.g., (23) and (24); or (ii) as the head of a compound form (3 out of 13); see (25) and (26). As the copula liid in Salaca Livonian and its cognate lìdõ in Courland Livonian are primarily associated with futurate and modal meanings (see Norvik 2012, 2015), one would expect to find liim(e)s lijms -forms with similar functions. The Salaca Livonian data set indeed contained instances of a futurate meaning (see 24 and 26) as well as a modal meaning, or more precisely an epistemic meaning, as the main function was to express uncertainty about a present situation (see 25 and 27).

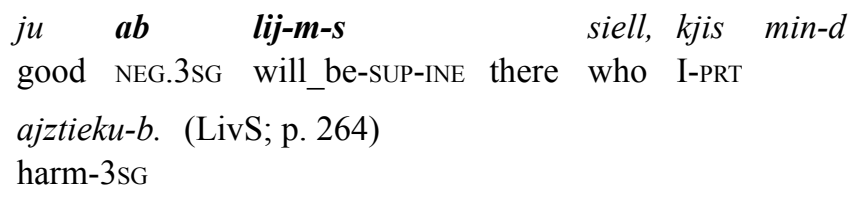


230 Miina Norvik, Helle Metslang, Karl Pajusalu

labbi nebuhs tam, kas manni aisteek (Lav)

good NEG:be:FUT.3SG this:DAT who I.ACC harm.3sG

'The one who harms me will not be good'

(24) $\boldsymbol{A b}$ lii-m-s Karl, muи kjis

NEG.3SG will_be-SUP-INE Karl other who

is-panu-b. (LivS; p. 309)

PFX-seem-3SG

[Es] wird nicht Karl sein, [es] scheint

it FUT.AUX.3SG NEG Karl be.INF it seem:3sG

jemand anderes (Ger)

someone else

nebuhs Kahrls, zittahds mannim isleekahs (Lav)

NEG:be:FUT.3sG Karls other.m I:DAT seem:3SG

'This is probably not Karl, [he] seems like someone else'

(25) $K u \quad$ lij-m-s jära juo-dets, sis

when will_be-SUP-INE PFV drink-PPP then

tul min-d kuts-ma. (LivS; p. 317)

come.IMP.2SG I-PRT call-SUP

Wenn ausgetrunken sein wird, dann komme,

when PFV:drink.PRF.PTCP be.INF FUT.AUX.3SG then come.IMP.2SG

mich zu rufen (Ger)

I.ACC to call.INF

kad buhs nodferts nahz manni faukt (Lav)

when be:FUT.3SG PFX:see:PPP.M come.IMP.2SG I.ACC call.INF

'When you have drunk it up then come call me'

(26) mina luotu-b, $k u$ täma lij-m-s tull-en. (LivS; p. 383)

I hope-1sG that s/he will_be-SUP-INE come-APP

Ich meine, dass sie gekommen sein wird (Ger)

I think:1SG that she come.PRF.PTCP be.INF FUT.AUX.3SG

es dohmaju ka wiņņa buhs nahkufe (Lav)

I think:1sG that she be:FUT.3SG come:PPP.F

'I hope that s/he has come' 
Although the Salaca Livonian texts contain about twice as many examples with lid used in its finite form (27 instances, in total) compared to the 13 instances of $\lim (e) s \sim \operatorname{lijms}$, the difference between them remains somewhat unclear. For instance, example (27) expresses epistemic modality just like example (26) does; example (26) and (27) as well as (25) and (28) are also similar construction-wise. Furthermore, there are examples suggesting that both forms are possible; see ex. (29). Still, there is some reason to argue that the function of the $m(V) s$-form is to add a certain emphasis - to set the focus on being in a particular state (cf. also section 1) ${ }^{4}$. Namely, the liim $(e) s \sim$ lijms -forms are used in copular constructions or in participle constructions expressing a state. To compare, the data set did not contain any examples of the supine inessive form appearing in an infinitival construction to express a future meaning or in a modal construction expressing a participant-external deontic meaning. However, due to the scarcity of data nothing more conclusive can be said.



Nun, ihr werdet [gewiss] geschlafen haben (Ger)

now you.2PL FUT.AUX.2PL certainly sleep-APP have.INF

$n u$, juhs buhfeet gullejufchi (Lav)

now you.2PL be:FUt.2PL sleep:APP.PL

'Now you must have slept'

(28) mis omme-l tie-d, sie lij-b tie-dets. (LivS; p. 305) what (your)self-AD;ALL do-2SG it will_be-3sg do-PPP

Was du dir tust, das wird getan sein (Ger) what you you:DAT do:2SG PRON FUT.AUX.3SG do:PPP be.INF ko pafcham darrees, tas buhs darrihts (Lav) what.ACC (your)self:DAT do-FUT.3sg this.m be:FUt.3sg do:PPP.M

'What you do for yourself will be done'

4 Serebrennikov (1963) regarded the supine constructions in the Finnic languages as instances of "emphatic conjugation"; according to him, the form is used when it is necessary to stress the fact that a situation takes place at a particular moment. The examples he presents can well be regarded as instances of locative-final, imminential, and progressive readings (see Norvik 2015: 39; see also section 1), but the emphatic functions should not be neglected either. 
(29) Sie jänim koug ab

lij

1. lii-me-s.

(LivS; p. 218)

it more long NEG.3SG will_be.CNG will_be-SUP-INE

Das wird nicht mehr lange sein (Ger)

PRON FUT.AUX.3SG NEG more long be.INF

det räcker ej länge (Swe)

PRON last.3SG NEG long

'It will not last longer'

In the insular dialect of Estonian as well as in Old Literary Estonian, one finds several examples of leeda (cognate of Livonian liid/lìdõ) used in the supine inessive construction; see ex. (30). There is also one such example from Courland Livonian presented by Sjögren and Wiedemann (1861a); see ex. (31). These examples can be associated with the expression of future time reference.

(30) sis teie lêe-te leid-ma-s (Insular Est; Wiedemann 2011: 531) then you.PL will_be-2PL find-SuP-INE

'Then you will find'

(31) Ta $\boldsymbol{l} \overline{\mathbf{t}} \boldsymbol{b}$

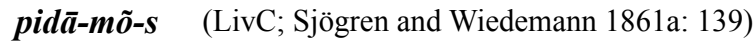

s/he will_be:3sG hold-SUP-INE

er wird halten (Ger)

he FUT.AUX.3sG hold.INF

'S/he will hold'

Examples (30) and (31) differ from Salaca Livonian in terms of their construction: namely, the Salaca Livonian liid occurs in its $m V S$-form but it does not tend to combine with the $m V S$-form itself (see examples 26,27 , and Table 2). Thus, this could again point to the fact that in the case of Salaca Livonian we are dealing with reanalysis of the Latvian future inflection. Namely in Latvian, the future tense is indicated with the $b \bar{u} t$ 'be' -form, including in compound forms (see also Endzelinns 1923: 665). 
234 Miina Norvik, Helle Metslang, Karl Pajusalu

(34)
$\begin{array}{lllll}\text { a. jeelis } & \text { sääl } & \text { olles } & n \ddot{a}-i z . & \text { (LivS; p. 323) } \\ \text { yesterday } & \text { there } & \text { be.CNV } & \text { see-PST.1SG }\end{array}$
Gestern dort seiend sah [ich] (Ger)
yesterday there be.PRS.PTCP see-PST.1SG I
wakkar tur buhdams redfeju (Lav)
yesterday there be.PrAP see:PST.1SG
b. Eile seal olles / *ole-ma-s nägin. (Est)
yesterday there be.CNV be-SUP-INE see-PST.1SG

Further support in favour of reanalysis - as a result of seeing similarities in form and/or function - comes from Courland Livonian. Namely, there are several examples of the supine form ending in $-m$ used with verbs of perception (see $35 \mathrm{a}$ ). It may be that instances like (35) are copies of the Latvian undeclinable present passive participle ending -am; see ex. (36). The am-participle is argued to be common with verbs of perception, such as 'to hear, 'to see' etc. (Hewson and Bubenik 1997; Endzelīns 1971: 251). To compare, in Estonian, the supine inessive (or the quotative form) would be used instead (see 35b).
a. Ma kūliz pi’n utā-m. (LivC)
I hear:PST.1sG dog bark-SUP
b. Ma kuulsin koera hauku-ma-s. (Est)
I hear:PST.1SG dog.PRT bark-SUP-INE

(36) Es dzirdēju zagli skrienam (Lav; Hewson \& Bubenik 1997: 158)

I hear:PST.1SG thief.PL.ACC run-PrPP

\section{Discussion and conclusions}

Based on the analysis of the data presented in 3.1 to 3.5 , we propose a tentative path of development for the forms and functions of the supine inessive predicate in Salaca Livonian (see Figure 1). 


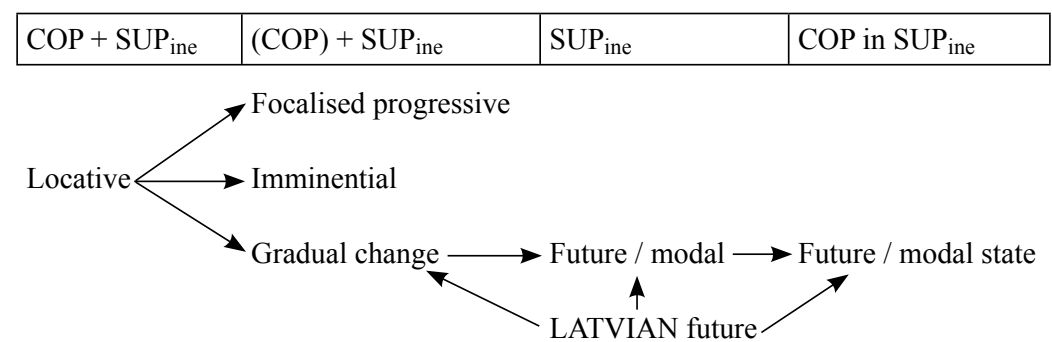

Figure 1. Dynamics of the Salaca Livonian supine inessive construction.

The Salaca Livonian data set contained examples of the present copula + the supine inessive form or the supine inessive by itself that were used to express a focalised progressive, imminential progressive, and gradual change. These three usages show similarities with the corresponding constructions in Estonian and Finnish that are originally also associated with an expression of location. Unlike in cognate languages, however, especially gradual change in Salaca Livonian tends to be expressed using the supine form as the sole predicate, i.e., without the copula 'be'. The material collected from Salaca Livonian does not support viewing this as an example of auxiliary ellipsis as this process could be expected to take place in a later phase of development (see Metslang 1995: 177). A more probable explanation is that we are dealing with reanalysis of the supine inessive $-s$ on the basis of the Latvian future inflection, which is also expressed with $-s$ in 3rd person. Usage of an infinite form as a predicate in Salaca Livonian could also be supported by the occurrence of the Latvian infinite forms as predicates.

We argue that the instances conveying gradual change are the primary stage of this development, as the implied future meaning is contained within the meaning of these forms. The next stage involves the usage of the supine predicates as finite forms to express a future meaning, although the underlying progressive construction may still be felt in the background. The final stage is represented by the instances of liid in futurate and modal constructions. Unlike in the previous stage, there is probably no reason to claim that the progressive construction is at play in the background.

The occurrences of the supine inessive constructions revealed that not only the future tense marker but also the Latvian participles could be reanalysed on the basis of similarities in the form. For instance, the use of the Salaca Livonian $m(V)_{s}$-forms as converbs could be influenced by 
the use of the Latvian present active participle ending in -dams; also, an instance of this possible reading seemed to copy the use of the Latvian present passive participle ending in -ams.

To conclude, the material analysed for the purposes of the present study showed synchronic variation representing both language-internal as well as contact-induced grammaticalisation. The contact-induced reanalysis appeared to be a combination of borrowing and calquing: the Salaca Livonian forms showed that the functions of the Latvian forms could have been copied as a result of seeing similarities in the form and function. Thus, despite the data being scarce, they turned out to be surprisingly multifaceted and enabled us to propose a possible path of development, which shows an intersection of internal and areal factors. Whereas the first stages of development of the Salaca Livonian supine inessive construction show similarities with the corresponding constructions in close cognate languages, the subsequent stages reveal strong Latvian influence. As its functions also differ from the corresponding construction in the other Livonian variety - Courland Livonian - there is reason in the future to also examine Latvian contact dialects.

\title{
Acknowledgements
}

This study was supported by the projects IUT2-37, PRG341, and "Livonian grammar and databases" financed by the Estonian Ministry of Education and Research.

\author{
Addresses: \\ Miina Norvik \\ Institute of Estonian and General Linguistics \\ University of Tartu \\ Jakobi 2 \\ 51005 Tartu, Estonia \\ E-mail:miina.norvik@ut.ee \\ Helle Metslang \\ Institute of Estonian and General Linguistics \\ University of Tartu \\ Jakobi 2 \\ 51005 Tartu, Estonia \\ E-mail: helle.metslang@ut.ee
}


Karl Pajusalu

Institute of Estonian and General Linguistics

University of Tartu

Jakobi 2

51005 Tartu, Estonia

E-mail: karl.pajusalu@ut.ee

\begin{abstract}
Abbreviations
1, 2, 3 - person, ACC - accusative, ADE - adessive, ALL - allative, APP - active past participle, ART - article, AUX - auxiliary, CNG - connegative, CND - conditional, COMP - comparative, DAT - dative, Est Estonian, F - feminine, Fin - Finnish, FUT - future, GEN - genitive, Ger - German, IMP - imperative, INE - inessive, INF - infinitive, INS instrumental, Lav - Latvian, LivC - Courland Livonian, LivS - Salaca Livonian, $\mathrm{M}$ - masculine, NEG - negative, $\mathrm{PFV}$ - perfective, $\mathrm{PFX}$ - prefix, PL - plural, PPP - passive past participle, PrAP - present active participle, PRF - perfect, PRON - pronoun, PrPP - present passive participle, PRT partitive, PST - past, Q - question particle, SG - singular, SUP - supine, Swe - Swedish, TRA - translative
\end{abstract}

\title{
References
}

Anthonissen, Lynn, Astrid De Wit, and Tanja Mortelmans (2016) "Aspect meets modality: a semantic analysis of German am-progressive". Journal of Germanic Linguistics 28, 1, 1-30.

Auziņa, Ilze, Ieva Breņķe, Juris Grigorjevs, Inese Indričāne, Baiba Ivulāne, Andra Kalnača, Linda Lauze, Ilze Lokmane, Dace Markus, Daina Nītiņa, Gunta Smiltniece, Baiba Valkovska, and Anna Vulāne (2013) Latviešu valodas grammatika. Rīga: LU Latviešu valodas institūts.

Bertinetto, Pier M., Karen H. Ebert, and Casper de Groot (2000) "The progressive in Europe". In Östen Dahl, ed. Tense and aspect in the languages of Europe, 517-558. Berlin and New York: Mouton de Gruyter.

Bybee, Joan, Revere Perkins, and William Paglicua (1994) The evolution of grammar: tense, aspect, and modality in the languages of the world. Chicago and London: University of Chicago Press.

Dahl, Östen (1985) Tense and aspect systems. Oxford and New York: Basil Blackwell. Duden-Grammatik = Duden. Die Grammatik, Hrsg. von der Dudenredaktion. 8., überarb. Aufl. Mannheim and Wien and Zürich: Dudenverlag, 2009. 
Ebert, Karen H (2000) "Progressive markers in Germanic languages". In Östen Dahl, ed. Tense and aspect in the languages of Europe, 605-653. Berlin and New York: Mouton de Gruyter.

EKS $=$ Erelt, Mati and Helle Metslang, eds. (2017).

Endzelīns [Endzelin], Jānis (1923) Lettische Grammatik. Heidelberg: Carl Winter.

Endzelīns, Jānis (1971) Comparative phonology and morphology of the Baltic languages. Transl. by William Schmalstieg and Benjamin Jēgers. The Hague: Mouton.

Erelt, Mati and Helle Metslang, eds. (2017) Eesti keele süntaks. Tartu: Tartu Ülikooli Kirjastus.

etTenTen corpus. Available online at $<\mathrm{http}: / / \mathrm{www} \cdot$ keeleveeb.ee/>. Accessed on 6.12.2016.

Holmes, Philip and Ian Hinchliffe (2003) Swedish: a comprehensive grammar. London: Routledge.

Hesselberg, Heinrich (1841) Lettische Sprachlehre. Mitau: Steffenhagen und Sohn.

Hewson, John and Vit Bubenik (1997) Tense and aspect in Indo-European languages: theory, typology, diachrony. Amsterdam, Philadelphia: John Benjamins Publishing Company.

LELS = Viitso, Tiit-Rein and Valts Ernštreits (2012).

$\mathrm{LL}=$ Latvian language. Available online at

$<$ http://www.latvianstuff.com/Language.html $>$. Accessed on 02.02.2018.

LVG = Auziņa, Ilze et al. (2013).

Metslang, Helle (1993) “Kas eesti keeles on olemas progressiiv?”. Keel ja Kirjandus 9, 470-476.

Metslang, Helle (1995) “The progressive in Estonian”. In Pier Marco Bertinetto, ed. Temporal reference, aspect and actionality. Vol. 2: Typological perspectives, 169183. Torino: Rosenberg \& Seller.

Metslang, Helle (2006) "Predikaat ajastut kogemas". Keel ja Kirjandus 9, 714-727.

Norvik, Miina (2012) "Periphrastic future devices in Salaca Livonian". Linguistica Uralica 48, 1, 27-40.

Norvik, Miina (2014) "Change-of-state predicates and their use in expressing the future: the case of Livonian". Journal of Estonian and Finno-Ugric Linguistics (ESUKAJEFUL) 5, 1, 117-148.

Norvik, Miina (2015) Future time reference devices in Livonian in a Finnic context. (Dissertationes Linguisticae Universitatis Tartuensis, 25.) Tartu: University of Tartu Press.

Serebrennikov, Boris Aleksandrovitš (1963) "Kategorija vremeni v pribaltijskofinskix jazykax”. Eesti keele süntaksi küsimusi, 426-511. (Keele ja Kirjanduse Instituudi uurimused, 7.) Tallinn.

Sjögren, Anders Johan, and Ferdinand J. Wiedemann (1861a) Joh. Andreas Sjögren's Livische Grammatik nebst Sprachproben. (Joh. Andreas Sjögren's Gesammelte Schriften. Bd. 2, Teil 1.) St. Petersburg.

Sjögren, Andreas J. and Ferdinand J. Wiedemann (1861b) Joh. Andreas Sjögren's livisch-deutsches und deutsch-livisches Wörterbuch. (Joh. Andreas Sjögren's Gesammelte Schriften. Bd. 2. Teil 2.) St. Petersburg. 
Thieroff, Rolf (2000) "On the areal distribution of tense-aspect categories in Europe". In Östen Dahl, ed. Tense and aspect in the languages of Europe, 265-305. Berlin and New York: Mouton de Gruyter.

Tommola, Hannu (2010) "Suunta ja muutos. Havaintoja viron ja suomen liikeverbeistä". Journal of Estonian and Finno-Ugric Linguistics (ESUKA - JEFUL) 1, 2, 311-340.

Viitso, Tiit-Rein (2008) Liivi keel ja läänemeresoome keelemaastikud. Tallinn: Eesti Keele Sihtasutus.

Viitso, Tiit-Rein and Valts Ernštreits (2012) Lìvõkīel-ēstikīel-lețkīel sõnārōntõz. Liivieesti-läti sõnaraamat. Lībiešu-igaunu-latviešu vārdnīca. Tartu and Rīga: Tartu Ülikool and Latviešu valodas aǵentūra.

Wiedemann, Ferdinand J. (2011 [1875]) Eesti keele grammatika. Ellen Niit, ed., Heli Laanekask, trans. Tallinn: Eesti Teaduste Akadeemia Emakeele Selts.

Winkler, Eberhard (1994) Salis-Livische Sprachmaterialien. (Veröffentlichungen des Finnisch-Ugrischen Seminars an der Universität München. Ser. C, 21.) München.

Winkler, Eberhard (1999) Ältere livische Sprachmaterialien. (Veröffentlichungen des Finnisch-Ugrischen Seminars an der Universität München. Ser. C, 22.) München.

Winkler, Eberhard and Karl Pajusalu (2016) Salis-Livisch I: J. A. Sjögrens Manuskript. Wiesbaden: Harrassowitz Verlag.

Winkler, Eberhard and Karl Pajusalu (2018) Salis-Livisch II: Grammatik und Wörterverzeichnis. Mit einem Anhang zu den salis-livischen Sprichwörtern. Wiesbaden: Harrassowitz Verlag.

\footnotetext{
Kokkuvõte. Miina Norvik, Helle Metslang, Karl Pajusalu: Supiini inessiivikonstruktsioon salatsiliivi keeles. Salatsi liivi keeles on supiini inessiivivorm kasutusel koopulat sisaldavas konstruktsioonis või iseseisva predikaadina, olles üldiselt seostatav progressiivsete ja tulevikuliste tähendustega. Uurimuses analüüsitava keelematerjali moodustavad salatsiliivikeelsed näitelaused koos läti-, saksa- ja/või rootsikeelsete tõlgetega. Materjal pärineb 19. sajandist, mil salatsiliivi keel kõlas veel liivi-läti kakskeelsete kõnelejate suus Läti põhjaosas. Siinse artikli eesmärgiks on käsitleda täpsemini supiini inessiivikonstruktsiooni funktsioone ja võimalikku arengut, sh ka kontaktist tingitud muutuse võimalikkust. Analüüsimisel on aluseks võetud funktsionaal-tüpoloogiline ja kasutuspõhine lähenemine. Artiklis näidatakse, et supiini inessiivivormi kasutusjuhtude hulgas on nii selliseid, mis annavad tunnistust keelesisesest arengust, kui ka selliseid, mis viitavad keelekontaktist tingitud arengule, täpsemini sarnast funktsiooni ja/või vormi kandvate läti vormide reanalüüsile.
}

Märksõnad: progressiiv, tuleviku väljendamine, kontaktist tingitud keelemuutus, finiidistumine, Salatsi liivi keel 
Kubbõvõttõks. Miina Norvik, Helle Metslang, Karl Pajusalu: Supīn inesīv formõd Salāts līvõ kīelsõ. Salāts līvõ kīelsõ supīn inesīv sōb kỗlbatõd īdskubs kopulaks agā ižkiz; ne formõd jemmitõt võibõd nägțõ progresīvizt ja tulbizāiga tẩntõkst. Kēra alīzõks ātõ kītõmõd Salāts līvõ kīels īdskubs lețkīel, saksā kīel ja/agā rūotškīel tulkõmõdõks. Materiāl um perīṇ 19. àigastsadāst, ku Salāts līvõ kīeldõ rõkāndizt līvõ- ja lețkēḷizt rovst Pūojlețmōl. Kēras um tuņšõltõd, mingizt ātõ supīn inesīv konstruktsijd funktsijd, ja kui ne ātõ suggõnd. Vel um vaņtõltõd, või mõitõks võib vỏlda perīṇ kīeld kontaktist. Analīz alīzõks um funktsionāli-tipologli tunšslimizmetōd ja kỗlbatimiz tunšllimi. Tunšslimi nägțõb, ku supīn inesīv formõd kỗlbatimi vaišti um seḷli, ku sīesõ āt nādõbõd suggimizt kīel eñtš sizāl, bet ātõ ka selllizt, mis āt perīn, kīeld kontaktist, ǐžkist form ja/agā funktsijd pūolst ītizt lețkēḷizt formõd reanalīzõd. 